\title{
OCCUPATIONAL STRESSORS AMONG NURSES WORKING IN URGENT AND EMERGENCY CARE UNITS
}

Denyson Santana PEREIRAa, Thamylles Sibelle Santana Lima ARAÚJO ${ }^{a}$, Cristiane Franca Lisboa GOIS José Prata GOIS JÚNIORc, Eliana Ofélia Llapa RODRIGUEZ ${ }^{\text {d }}$, Valmira dos SANTOS ${ }^{\mathrm{e}}$

\section{ABSTRACT}

The study aimed to assess occupational stressors among nurses working in urgent and emergency care facilities. It is a descriptive research developed in two public hospitals of different complexity degrees, with 49 nurses. Data were collected from June to September 2011. The Bianchi's Stress Scale, which is composed of six domains: Relationship, Unit functioning, Staff management, Nursing care, Unit coordination, and Work conditions was used to assess occupational stressors based on the regular activities performed by nurses. Data were analyzed by using descriptive statistics and Mann Whitney-U test. For the nurses working in the high complexity healthcare facility - hospital A the most stressful domain was Nursing care, while for those professionals working in the medium complexity healthcare facility - hospital B, Staff management was the most stressful domain. The nurses from hospital A perceived carerelated activities as more stressful, while for those in hospital B administrative activities were considered more stressful.

Descriptors: Psychological stress. Nursing. Emergency service, hospital. Emergency relief.

\section{RESUMO}

O estudo objetivou avaliar os estressores laborais entre enfermeiros que trabalham em unidades de urgência e emergência. Trata-se de uma pesquisa descritiva, desenvolvida em dois hospitais públicos de complexidade diferente, com 49 enfermeiros. Os dados foram coletados no periodo de junho a setembro de 2011. Para a avaliação dos estressores, a partir das atividades realizadas pelos enfermeiros, foi utilizada a Escala Bianchi de Stress, composta por seis domínios: Relacionamento, Funcionamento da unidade, Administração de pessoal, Assistência de enfermagem, Coordenação da unidade e Condições de trabalho. Os dados foram analisados por estatística descritiva e realização do teste de Mann-Whitney. As atividades mais estressantes para os enfermeiros do hospital de alta complexidade (A) estão relacionadas ao domínio Assistência de enfermagem, e, para os de média complexidade (B), ao domínio Administração de pessoal. Os enfermeiros do hospital A perceberam como atividades mais estressantes as relacionadas ao cuidado, e os do $B$, as relacionadas à área administrativa.

Descritores: Estresse psicológico. Enfermagem. Serviço hospitalar de emergência. Socorro de urgência. Título: Estressores laborais entre enfermeiros que trabalham em unidades de urgência e emergência.

\section{RESUMEN}

El estudio tuvo por finalidad evaluar los estresantes laborales entre enfermeros que trabajan en unidades de urgencia y emergencia. Se trata de una investigación descriptiva, realizada con 49 enfermeros de dos hospitales públicos de complejidad diferente. Los datos fueron recolectados durante junio a setiembre de 2011. Para evaluar los estresantes en las actividades realizadas por los enfermeros fue utilizada la Escala de Bianchi de Estrés constituida de seis dominios: Relacionamiento, Funcionamiento de la unidad, Administración de personal, Asistencia de enfermería, Coordinación de la unidad y Condiciones de trabajo. Los datos analizados descriptivamente y con el test de Mann Whitney. Las atividades más estresantes para los enfermeros del hospital de alta complejidad (A) están relacionadas al dominio Asistencia de enfermería. Para el de media complejidad (B) fue el dominio administración de personal. Enfermeros del hospital A percibieron como actividades más estresantes las relacionadas al cuidado y los del B las actividades administrativas.

Descriptores: Estrés psicológico. Enfermería. Servicio de urgencia en hospital. Socorro de urgencia.

Título: Estresantes laborales entre enfermeros que trabajan en unidades de urgencia y emergencia.

a Nurse. Aracaju, Sergipe (SE), Brazil

a Nurse. Aracaju, SE, Brasil.

b Nurse. PhD in Nursing. Professor at Universidade Federal de Sergipe (UFS). Aracaju, SE, Brazil.

c Advogado. Experience in Labor Law. Aracaju, SE, Brazil.

d Nurse. PhD in Nursing. Professor at UFS. Aracaju, SE, Brazil.

e Nurse. PhD in Nursing. Professor at Faculdade de Sergipe (FASE). Aracaju, SE, Brazil. 


\section{INTRODUCTION}

Nurses usually perform functions carried out by other professionals, such as: sector and staff management, health education of the nursing staff, patient/client and family, and assistance/care of patient/client. This accumulation of functions, associated with the job-related skills and requirements, may cause stress and impact the nurse's work, health, and quality of life. Thus, the literature reports that the nursing profession may produce occupational stress ${ }^{(1)}$.

The first analyzes of stress were made by an endocrinologist in the 30's ${ }^{(2)}$. He borrowed the word "stress" from physics in an attempt to describe the set of the non-specific physiological responses to a stressor and that requires adaptation. The agent that triggers this physiological reaction was called stressor. The studies conducted by the referred endocrinologist encouraged several others, in different health care areas, providing different ways to understand and address the concept of stress.

In the nursing field this concept is used by theorists who include other variables, besides the biological one, in an attempt to understand the individual and groups in a holistic approach ${ }^{(3-4)}$. Studies show the use of this word in various aspects of nursing care ${ }^{(5)}$, e.g. in urgency and emergency care ${ }^{(6)}$.

In these segments, the health care professionals who assist patients in serious or potentially serious situations need a physical structure, technology and expertise that promote effective communication between the members of the healthcare team. In the state of Sergipe, the work conditions of nurses in urgent and emergency care departments of public hospitals are not suitable, which may jeopardize the ability to manage conflicts and provide assistance to users. This context, associated to the personal ability to handle potentially stressful situations, can cause damage to the health of nurses.

Given the importance of identifying what are the most significant stressors for nurses, in every sector, in order to suggest actions to reduce the impact of stress on the lives of these professionals, the present study aimed to assess occupational stressor among nurses who work in urgent and emergency care departments of public hospitals of Aracaju, capital of the state of Sergipe.

\section{METHOD}

This is a descriptive, cross-sectional study, using a quantitative approach conducted in two public hospitals of Aracaju, which were designated in this study as hospitals A and B. Hospital A is a high complexity healthcare facility that assists users who live in the state of Sergipe and the surrounding states of Alagoas and Bahia. Hospital $\mathrm{B}$ is a medium complexity healthcare facility for users who live in Aracaju. After completion of data collection, hospital B became an emergency care unit.

Both hospitals are intended for clinical patients and trauma victims of all ages, but only hospital A is prepared to perform surgical procedures. Comparison of the number of attendances in both hospitals showed that hospital A attends a larger number of patients than hospital B, which can be explained by the fact that it is the largest public hospital in the state and also a referral service for cities of neighboring states.

The sample was composed of 49 clinical nurses who provided direct care to patients in the morning, afternoon and night shifts, and who worked in the urgent and emergency sectors of hospital A or B. The inclusion criteria were working at these sectors for at least six months in the referred units. Nurses who worked in other units did not participate in the study, even if they sometimes cared for patients in the urgent and emergency care units. At first, the sample was composed of 64 nurses, but five did not return the questionnaires and 10 were on sick leave or vacation at the time of data collection.

The study was approved by the Research Ethics Committee of Universidade Federal de Sergipe (CAAE 0057.0.107.000.11). The collection period occurred during the months of June to September 2011. The participants in the study were duly informed on the research, care and rights ensured to them, and were told that the information obtained would not allow their identification and that non-participation in the study would not create any problems regarding their status in the hospital. Following agreement to participate in the study the nurses signed the Informed Consent Form.

Two instruments were used in the study: one containing sociodemographic and clinical 
data (marital status, children (if any), information on stress-related problems or use of psychoactive substances) and professional (weekly workload, number of jobs, remuneration, number of people dependent on the nurse's income, period of time working as a nurse and in the hospital, intention to change job, number of night shifts per month) and a second instrument for assessment of work stress.

Some instruments allow assessing stress at work, such as the Stress Inventory for Nurses ${ }^{(7)}$, the Job Stress Scale ${ }^{(8)}$ and Bianchi's Stress Scale ${ }^{(9)}$. In the present study, the Bianchi's Stress Scale (BSS) was adopted ${ }^{(9)}$. It has been used in studies with nurses who worked in urgent and emergency care ${ }^{(10)}$, and in other sectors ${ }^{(11-1)}$, and has shown good internal consistency, with Cronbach's Alpha considerably high $(0.8366)^{(13)}$.

The BSS was developed and validated in Brazil by Bianchi ${ }^{(9)}$. The instrument is aimed to identify and classify the levels of stress in the hospital setting considering the activities performed by nurses. The BSS has two parts: the first characterizes the sample. The second is formed by a Likert-type scale, composed of 51 items, ranging from 0 to 7 points, where 1 means "little stressful", 4 "average level" and 7 "highly stressful". The value $O$ (zero) indicates that the activity is not performed. The items can be grouped in six domains, making it possible to identify those of higher intensity and associate them to the level of stress of the nurse. Domain A: Relationship with other units and supervisors (nine items: 40 to $46,50,51$ ); Domain B: Activities related to the proper functioning of the unit (six items: 1 to 6); Domain C: Activities related to staff management (six items: 7 to 9,12 to 14 ); Domain D: nursing care provided to the patient (15 items: 16 to 30); Domain E: Coordination of the activities performed in the unit (eight items: 10, 11, 15, 31, 32, 38, 39, 47); Domain F: Working conditions for the accomplishment of nursing activities (seven items: 33 to $37,48,49)^{(9)}$.

The study used the three types of analyzes allowed by the scale: Total score: non-zero sum. The result may range from 51 (all activities are slightly stressful) to 357 (all activities are highly stressful); Average score for each item (stressor): the total value of the assessed stressor is obtaining with the sum of the values assigned for each item and subtrac- tion by the zero value. The average score that can range from 1.0 to 7.0 is obtained by dividing the total by the number of respondents who indicated nonzero values for that item. Score for each domain: in the end, the average score is obtained by summing the total score of the domain by the number of its items. Score equal to or lower than 3.0 - low stress level; between 3.1 to 5.9 - average level; equal to or higher than $6.0-$ high level ${ }^{(9)}$.

Data were stored in Microsoft Excel Starter 2010 software and analyzed in the Assistat. Descriptive statistical analyzes of single frequency for nominal/categorical variables of central tendency (mean and median) and dispersion (standard deviation) for continuous variables were performed. A Mann-Whitney test for independent samples was used for comparison between the groups.

\section{RESULTS}

Among the nurses who participated in the study in hospitals A and B, respectively, most had 40 years or less (96.7\% and $78.9 \%)$, were women (76.7\% and $73.7 \%)$, had no children $(76.7 \%$ and $52.6 \%)$, had graduated within 10 years or less (90\% and $68.4 \%)$, worked $21-40$ hours per week $(53.3 \%$ and $52.6 \%)$, did not wish to change their professional area $(63.3 \%$ and $57.9 \%)$, and had completed postgraduate courses in the area of health $(80 \%$ and $89.5 \%)$. Concerning postgraduate courses, eight and four nurses had attended such courses in urgent and/or emergency care in hospitals A and B, respectively. In hospital A, $33.4 \%$ of the nurses worked with a teammate and in hospital B, 52.6\%. The average earnings were 2.987,27 reais for nurses of hospital A and $4.311,95$ reais for those in hospital B. As for the number of employment contracts, $40 \%$ of the nurses of hospital A and $84.2 \%$ of those from hospital B had two or more employment contracts. The average working time in the unit was 1.83 years for the nurses in hospital $\mathrm{A}$ and 3.63 years for those in hospital B.

With respect of problems resulting from stress and the use of psychoactive substances, $70 \%$ of the nurses reported having or having had such problems in the past and $20 \%$ of the subjects used or have previously made use of psychoactive substances. 
For assessment of stress levels, the variation of the total score of BSS was calculated. In hospital A the variation was 59-242 points, and in hospital B, 84-276 points.

According to the average score of each item, the five main stressors for nurses of hospital A were: perform tasks with minimum time available, attend emergency cases in the unit, Interact with relatives of critically ill patients and noise level in the unit, prepare the monthly scale of employees and the physical environment of the unit. And for nurses of hospital $\mathrm{B}$, the main stressors were: monitor the nursing staff, be responsible for staff assignment, supervise team activities, prepare the monthly scale of employees, the physical environment of the unit and monitor the quality of care. The stressors "prepare the monthly scale of employees" and "the physical environment of the unit" obtained the same score in the analysis of nurses from the two hospitals (Table 1).
Assessment of stressors by domain in hospitals $\mathrm{A}$ and $\mathrm{B}$, in order, was, respectively, delineated, as follows: $\mathrm{E}<\mathrm{C}<\mathrm{F}<\mathrm{B}<\mathrm{A}<\mathrm{D}$ and $\mathrm{A}<\mathrm{B}<\mathrm{E}<\mathrm{D}<\mathrm{F}<\mathrm{C}$, with no coincidence between the most and least stressful areas in the two analyzed institutions. However, there was only statistically significant difference $(\mathrm{p}<0.05)$ between the nurses of the two hospitals in the domains A and $\mathrm{C}$ (Table 2).

For the nurses in hospital A, the domains Care provided to patient by nurses, relationship with other units and supervisors, Activities related to the proper functioning of the unit, and Working conditions for the development of nursing activities showed average levels of stress, while for nurses of hospital B the domains were: Activities related to staff management and Working conditions for the development of nursing activities (Table 2).

Table 1 - Position of the 10 most stressful items in urgent and/or emergency sectors, according to the nurses. Aracaju, 2011.

\begin{tabular}{lcccc}
\hline \multirow{2}{*}{\multicolumn{1}{c}{ Stressor }} & \multicolumn{2}{c}{ Hospital A } & \multicolumn{2}{c}{ Hospital B } \\
\cline { 2 - 5 } & $\mathbf{P}$ & $\mathbf{M} \pm$ S.D. & P & M \pm S.D. \\
\hline Perform tasks with minimum time available & 1 & $5.44 \pm 1.8$ & 9 & $4.37 \pm 2.2$ \\
Attend emergency cases in the unit & 2 & $5.37 \pm 1.6$ & & \\
Interact with relatives of critically ill patients & 3 & $5.34 \pm 1.6$ & 8 & $4.47 \pm 1.4$ \\
Noise level in the emergency room unit & 3 & $5.34 \pm 2.3$ & 7 & $4.53 \pm 2.1$ \\
Prepare the monthly scale of employees & 4 & $5.20 \pm 1.3$ & 4 & $4.86 \pm 1.9$ \\
Physical environment of the unit & 5 & $5.10 \pm 2.3$ & 5 & $4.79 \pm 2.1$ \\
Monitor the quality of care. & 6 & $4.97 \pm 1.7$ & 5 & $4.79 \pm 1.6$ \\
Tackling patient's death & 7 & $4.83 \pm 1.8$ & 6 & $4.63 \pm 2.2$ \\
Develop routines, rules and procedures & 8 & $4.80 \pm 2.1$ & & \\
Meet the needs of family members & 9 & $4.73 \pm 2.1$ & & \\
Request review and repair of equipment & 10 & $4.70 \pm 1.9$ & & \\
Coordinate the activities performed in the unit & & & 10 & $4.33 \pm 1.4$ \\
Monitor the nursing team & & & 1 & $5.58 \pm 1.5$ \\
Staff assignment & & & 2 & $5.11 \pm 1.5$ \\
Supervise team activities & & & 3 & $4.89 \pm 1.5$ \\
\hline
\end{tabular}

P - Position; M - Mean (average); S.D. - Standard deviation.

Source: research data. 
Table 2 - Descriptive statistics of BSS scale domains, according to the nurses. Aracaju, 2011.

\begin{tabular}{cccccc}
\hline \multirow{2}{*}{ Domains } & \multicolumn{2}{c}{ Institution A } & \multicolumn{2}{c}{ Institution B } & \multirow{2}{*}{$\boldsymbol{p}^{*}$} \\
\cline { 2 - 5 } & $\mathbf{M} \pm$ S.D. & Interval & $\mathbf{M} \pm$ S.D. & Interval & \\
\hline $\mathrm{D}$ & $3.42 \pm 1.0$ & $1.00-4.93$ & $2.91 \pm 0,9$ & $1.20-4.53$ & $>0.05$ \\
$\mathrm{~A}$ & $3.40 \pm 1.3$ & $0.89-6.33$ & $1.94 \pm 1.0$ & $0.78-5.11$ & $<0.05$ \\
$\mathrm{~B}$ & $3.17 \pm 1.6$ & $0.00-6.50$ & $2.86 \pm 1.7$ & $0.67-5.83$ & $>0.05$ \\
$\mathrm{~F}$ & $3.15 \pm 1.0$ & $1.00-5.29$ & $3.26 \pm 1.2$ & $2.14-6.86$ & $>0.05$ \\
$\mathrm{C}$ & $2.92 \pm 1.4$ & $0.67-6.50$ & $3.95 \pm 1.4$ & $1.50-6.83$ & $<0.05$ \\
$\mathrm{E}$ & $2.65 \pm 1.3$ & $0.50-5.75$ & $2.88 \pm 1.2$ & $1.38-5.63$ & $>0.05$ \\
\hline
\end{tabular}

A - Relationship with other units and supervisors; B - Activities related to the proper functioning of the unit; C - Activities related to staff management; D - Nursing care provided to the patient; E - Coordination of the activities performed by nurses in the unit; F - Working conditions for the development of nursing activities. * Mann-Whitney test.

Source: research data.

\section{DISCUSSION}

In the present study, most nurses were 40 years of age or younger, and in hospital A the group older than 20 and younger than 30 years accounted for $70 \%$ of the sample. Also, a predominance of females was observed, consistent with the profile of Brazilian nurses ${ }^{(6-7,10,13-14)}$. In 2010, according to analyses provided by the Federal Board of Nursing, $88.02 \%$ of Brazilian nurses were women ${ }^{(15)}$.

The advances that made it possible for women to enter the labor force have also resulted in excessive workload, although the literature reports that, in what regards nursing, the family environment may provide support to alleviate the stressors of the workplace ${ }^{(7)}$.

Most nurses had graduated within five years or less and had not specialization in urgent and emergency care. Postgraduate studies may reduce stress, as knowledge allows for greater control of the situation, and, thus, better care for the patients ${ }^{(14)}$.

The percentage of nurses who worked more than 40 hours per week was as follows: $40 \%$ and $47,4 \%$ in hospitals $\mathrm{A}$ and $\mathrm{B}$, respectively, which is explained by the fact that $40 \%$ and $84.2 \%$ of the nurses who worked in the referred institutions had two employments. This situation, i.e., nurses working in two or more health care institutions, without time for leisure, family life and rest, is a matter of concern. The recognition that workers in the healthcare industry are underpaid, their income being insufficient to meet the needs of their families, explains the need for health professionals to have more than one job ${ }^{(16)}$.

Regarding the most stressful activities, some of our results corroborate the literature. Studies with nurses who worked in high-complexity healthcare facilities, the activities "perform tasks with minimum time available"(10,12), "interact with relatives of critically ill patients"(10), "noise level in the unit" and "the physical environment of the unit" ${ }^{\prime 12)}$ were some of the most stressful activities, as in the present study, particularly for nurses of hospital A. Importantly, in one study ${ }^{(12)}$, only $24.7 \%$ of the sample was composed by nurses who worked in urgent/emergency care facilities.

Hospital A assists a larger number of patients at risk of imminent death, and has also a larger number of nurses working in urgent and emergency care compared to hospital B, characteristics that may explain why "working conditions for the accomplishment of nursing activities" and "nursing care provided to the patient", were the domains that included most stressful activities for nurses of hospital A, and also why the latter was considered the domain that generated the highest amount of stress for nurses of hospital A.

The domain, "relationship with other units and supervisors", was the second most stressful area for nurses in hospital A, while for nurses in hospital B this domain was the least stressful, which is consistent with observations of other authors 
who conducted studies with nurses who worked in urgent and emergency care facilities ${ }^{(10)}$. One possible explanation is that hospital $\mathrm{B}$ is smaller than hospital A, which favors contact with other units and sectors.

The domain considered the most stressful for nurses of hospital B was "activities related to staff management", and activities "monitor the nursing team", "assignment of staff" and "supervise team activities", considered the most stressful. Thus, some authors report that the managerial activity performed by nurses who interact with the nursing team generates stress ${ }^{(12)}$.

Stress has been investigated in different nursing areas, and, regardless of the sector, n nursing is considered a stressful occupation. Reducing the stressors indicated by these nurses depends not only on them, but also on those responsible for the management of the institution.

\section{CONCLUSIONS}

In the present study, we assessed the stressors identified by the nurses, taking into consideration the workplace, which allowed a more accurate vision, and provided support for a plan of action aimed at reducing the stress experienced by the nurses who work in the urgent and emergency care units surveyed.

It can be concluded that the nurses who worked in the urgent and emergency care units were stressed at the time of data collection, with negative repercussions for their work. Analysis of the most stressful activities showed differences between the two institutions. Regarding the domains, the nurses of hospital A perceived care-related activities as more stressful, while nurses in hospital B found administrative activities more stressful.

The findings of this research will be used to promote changes in the working conditions of nurses in order to mitigate the impact of occupational stressors on the life of these professionals, such as: professional improvement, less working hours, career planning, better communication between managers and workers, more freedom for the decision-making process, meetings to discuss problems and improvements, mutual assistance in the health team.

One limitation of this study was the impossibility of collecting data from nurses who worked in urgent and emergency care in private hospitals.

\section{REFERENCES}

1 Rocha MCP, Martino MMF. O estresse e qualidade de sono do enfermeiro nos diferentes turnos hospitalares. Rev Esc Enferm USP. 2010;44(2):280-6.

2 Selye H. The stress of life. New York: McGraw Hill; 1956.

3 Watson J. Conceptual for nursing pratice. Norwalk: Appeton Elange; 1998.

4. Neuman B, Young RJ. The Betty Neuman Model: a total person approach to viewing patient problems. Nurs Res. 1972;21(3):385-94.

5 Bianchi ERF. Enfermeiro hospitalar e o stress. Rev Esc Enferm USP. 2000;34(4):390-4.

6 Ritter RS, Stumm EMF, Kirchner RM. Análise de Burnout em profissionais de uma unidade de emergência de um hospital geral. Rev Bras Enferm. 2009;11(2):236-48.

7 Stacciarini JM, Tróccoli BT. O estresse na atividade ocupacional do enfermeiro. Rev Latinoam Enferm. 2001;9(2):17-25.

8 Karasek R, Theorell T. Healthy work: stress, productivity and the reconstruction of working life. New York: Basic Books; 1990.

9 Bianchi ERF. Escala Bianchi de stress. Rev Esc Enferm USP. 2009;43(Esp):1055-62.

10 Menzani G, Bianchi ERF. Stress dos enfermeiros de pronto socorro dos hospitais brasileiros. Rev Eletrônica Enferm. 2009;11(2):327-33.

11 Versa GLGS, Murassaki ACY, Inoue KC, Augusto de Melo W, Faller JW, Matsuda LM. Estresse ocupacional: avaliação de enfermeiros intensivistas que atuam no período noturno. Rev Gaúcha Enferm. 2012;33(2):78-85.

12 Lima GF, Bianchi ERF. Estresse entre enfermeiros hospitalares e a relação com as variáveis sociodemográfica. REME Rev Min Enferm. 2010;14(2):210-8.

13 Guerrer FJL, Bianchi ERF. Caracterização do estresse nos enfermeiros de unidades de terapia intensiva. Rev Esc Enferm USP. 2008; 42(2):355-62. 
14 Montanholi LL, Tavares DMS, Oliveira GR. Estresse: fatores de risco no trabalho do enfermeiro hospitalar. Rev Bras Enferm. 2006;59(5):661-5.

15 Conselho Federal de Enfermagem (COFEN), Departamento de Tecnologia da Informação. Análise de dados dos profissionais de enfermagem existentes nos Conselhos Regionais [Internet]. Brasília (DF);
2011 [citado 2011 Nov 01]. Disponível em: http:// site.portalcofen.gov.br/sites/default/files/pesquisaprofissionais.pdf.

16 Pafaro RC, De Martino MMF. Estudo do estresse do enfermeiro com dupla jornada de trabalho em um hospital de oncologia pediátrica de Campinas. Rev Esc Enferm USP. 2004;38(2):152-60.

\author{
Author's address / Endereço do autor / \\ Rua Cláudio Batista, S/N, Sanatório \\ 49060-108, Aracaju, SE \\ E-mail: cristianeflg@hotmail.com
}

